\title{
Human Right Awareness and Advocacy Role of Youth in Kerala: An Empirical Analysis
}

\author{
K. M. Ashifa \\ Department of Social Work, Faculty of Health Science, Istanbul Gelisim University, \\ Istanbul - Turkey. Email: ashifakattur@gmail.com
}

\begin{abstract}
Human rights are inherent with our nature and are essential as they provide dignity, freedom and protection. Human rights awareness is an ability of individual to have consciousness on their basic rights. It is vital to address the underlying causes of human rights violations, prevent human rights violations, fight racism, promote equality and increase participation of citizens in democratic decision-making (Council of European Portal, 2017). Transformational human rights learning imbues people with knowledge that world should be and can be different. Practice, opportunities to learn new lessons and skills are a core element of human rights learning (Tolman, 2000). Active youth participation in the process of inculcating human right values for combat violations and create a society with justice and peace. They can disseminate information on human rights and it can make youth as advocates of human rights. The present study focused to find the role of youth to protect human rights and their involvement in the activities of welfare programmes as National Service Scheme (NSS) and Nehru Yuva Kendra (NYK). The study showed that awareness of the human rights of youth and their efforts to protect their rights are positively interrelated, as awareness can lead to advocacy and this is achieved through NSS and NYK programs.
\end{abstract}

Key Words: Human Rights Education, Youth, Participation and Protection

\section{Introduction}

Human rights are the fundamental rights and freedoms entitled to all human beings. Civil and political rights include human rights, such as the right to life, democracy, freedom of expression and equality before the law. Social, culture-based and economic rights are also essential to safeguard human security and to maintain human dignity. The rights to participation in culture, to food, to work and to education are essential to protect human security (United Nations, 2014). Human rights are necessary pre requisites for survival and existence of human society. It holds the inspiring vision of a world that is free, fair and peaceful and sets minimum standards for individuals and institutions. Transformational human rights learning imbues people with knowledge that the world should be and can be different. It empowers people to take action wherever they are equipped with a vision to see a better world and the tools to begin that transformation. The educated youth can impart knowledge and create consciousness to the people. Youth are actively involved in the process of instilling skills and human rights principles in the fight against rights violations and building a society with justice and peace. They will share human rights knowledge and promote human rights for young people.

Human rights awareness is an ability of individuals to have consciousness on their basic rights. It is fundamental for addressing the underlying causes of human rights violations, preventing human rights abuses, combating discrimination, promoting equality and enhancing

(C) AesthetixMS 2020. This Open Access article is published under a Creative Commons Attribution Non-Commercial 4.0 International License (http://creativecommons.org/licenses/by-nc/4.0/), which permits non-commercial re-use, distribution, and reproduction in any medium, provided the original work is properly cited. For citation use the DOI. For commercial re-use, please contact editor@rupkatha.com. 
people's participation in democratic decision-making processes (Council of European Portal, 2017). Awareness of human rights mechanisms, substantive and collective rights is intended to promote the commitment to fostering a mutual understanding of human rights between governments and their citizens in order to re-affirm values of human dignity and equality for future generations. (United Nations, 2008). Advocacy aims to influence the outcome, including decisions about the distribution of public policies and resources, within political, economic and social systems that directly affect people's lives. This has always been part of the professional practice of bringing human rights into society by including participation and involvement in networking, capacity building, mobilization of capital, the protection of rights, without disregarding obligations, policy changes and changes in attitude among the public (Sarfaty, 2009). It may include many activities that a person or organization undertakes through media, campaigns, sensitization, networking, lobbying and litigation. It leads to make a violation free society which respects the worth and dignity of the individual and group. Advocacy is considered as core intervention strategy to practice human rights principles and values.

\section{Review of Literature}

The human rights movement and its reactionary effect throughout the world in the $21^{\text {st }}$ century have been traced by Human Rights Watch (2013). The entire movement remains impressively resilient, able to fight conservative efforts. But individual parts of the movement, especially the defenders, are still vulnerable to organizations and need support. The effectiveness of such actions should not only rely on the bravery of human rights defenders. The human rights movement has the support of its allies and demands that the individuals and values under attack stand up more strongly even when the perpetrators are an ally. The 1948 Universal Declaration of Human Rights may be considered as the embodiment of the universal human rights standards. It outlines the fundamental freedoms and rights which everyone on earth has in common. It is not legal, but obliges the Member States to include its provisions in their national constitutions and laws (Thakkar,1997).

Kaur (2009) pointed out that human rights promotion and protection have its own meaning and scope in a pluralistic society such as India. Societal violations of human rights have mandated human rights training at all levels of teachers ' schools and education. Assessment of human rights values should transcend statements and become a reality and a life style. The awareness of human rights in India has only passed the initial steps on the road towards achieving human rights education objectives.A holistic action plan with a clean objective of human rights education can be developed, a functional and compound curriculum framework for the various stages of education, an established curriculum for teaching, education policy for teachers and teachers, and a self-learning package - including material on general awareness and development of skills (Kenya, 2014).

Integrating youth into a non-profit organization as decision makers presents certain legal questions concerning their status. As volunteers, young people have proven valuable resources through time and talent according to Allen (2002). The young people have the ability, the energy, responsibility and the right to make life decisions. They have also the right to learn life skills and social skills to become empowered adults. Advocacy with young people is always a way of respecting human rights (Flanagan, C. A., \& Christens, B. D. (2011). This view dismisses the ways in which young people are not empowered and, at best, the young person still relies on social structures. The review found that many studies on the perception of human rights and the role of young people received comparatively less attention from scholars. The review emphasizes the 
importance of an integrated youth study to advance human rights in this context. This work has therefore highlighted the concern of young people about human rights and their role in supporting human rights.

\section{Objective of the Study}

The present study has been analyse the advocacy role and human rights awareness among the youth in Kerala.The youth welfare programmes of NSS and NYK serves as focal point for developing activities for student as well as non-student youth, particularly in rural areas to provide opportunities for development of their personality and skills enabling them to act as vanguards in the process of development. Their contribution in the field of human rights was scrutinized in the study.

\section{Method of Study}

The study undertaken among youth in Kerala especially with the youth volunteers of National Service scheme and youth club members of Nehru Yuva Kendra. The survey was intended to find out the human rights situation and the participation of youth in promoting and protecting human rights in the community. The human rights awareness level and advocacy effort of youth on human rights promotions have been analysed.

\section{Major Findings}

Protection of human right Through NSS and NYK: National service scheme is a program focusing on students and a noble experiment in the field of academic extension. It succeeds in creating a sense of belonging, brotherhood and harmony between young people. The main focus of the NSS was on environmental protection, health guidelines, acquisition of skills, value education and legal guidelines. NSS conducted various programmes for protecting environment like planting trees, green campus and plastic free campaign, waste is wealth programmes and energy conservations programme. The environmental protection programs of NSS were mainly designed to safeguard the right to a healthy environment. The Public action projects have carried out sanitation drives, awareness initiatives for mental health, medical schools, blood donor schemes, pulse polio immune systems, anti-tobacco campaigns. The study further demonstrates that the NSS organized professional training, personality development and the acquisition of communication skills to guarantee the right to adequate living standards. In order to foster human value and harmonious society, seminars and conferences on communal harmony, peacebuilding, secularism and national integration are held. The study shows that the district cell of NSS Thrissur conducted various programs of juridical orientation with cooperation from KELSA, DELSA, bar associations and the department of vehicles. Sensitivity programs focused on basic human rights, consumer rights, social security measures, gender justice and domestic violence campaigns.

Table 1

Awareness on Human Rights Violations**

\begin{tabular}{|l|l|l|l|}
\hline Human Rights Violation & Aware & Not Aware & No opinion \\
\hline
\end{tabular}




\begin{tabular}{|c|c|c|c|}
\hline Child Labour & 89.4 & 10.6 & o.o \\
\hline Human Trafficking & 42.3 & 30.0 & $27 \cdot 7$ \\
\hline Sexual Harassment & 83.4 & 10.6 & 6.0 \\
\hline Caste Discrimination & 73.5 & 12.4 & 14.1 \\
\hline Child Abuse & 84.6 & 6.2 & 9.2 \\
\hline Domestic Violence & $79 \cdot 3$ & 12.8 & $7 \cdot 9$ \\
\hline \multicolumn{4}{|c|}{ *Figures in Parenthesis represent percentage } \\
\hline
\end{tabular}

Table 1 revealed that 89.4 percent of the youth opinioned that child abuse is the worst form of human rights violation and the State has to provide basic requirements for the development and protection of the child. Human trafficking, sexual harassment and domestic violence were the most notable human rights violation of women. Child abuse indicated as violation of child rights at 84.6 percent is rights violation. The study further revealed that 79.6 percent considered domestic violence as a form of human rights violation and it has to be prevented by Protection of Women from Domestic Violence Act 2005.

Youth Involvement in Human Rights Protection and Promotion: Newspaper was the major source knowledge about human rights for youth (86.6 percent) and other media channels such as TV/radio accounted for 63.5 percent of youth. The study revealed that 60.7 percent of the NSS volunteers participated in human rights training programmes, but the participation of NYK club members were only 41.7 percent. As per the findings 53.6 percent of the youth attended seminar and 54.7 percent attended special lecture sessions on human rights. The youth were involved in various human rights activities through NSS and NYK. Political parties, voluntary organizations and other social activity clubs also senisitize the youth to Human Rights. 49 percent were involved in the human rights activities. As per the opinion of youth child labour (89.4 percent), human trafficking (42.3 percent), sexual harassment (63.4 percent), Caste discrimination (63.5 percent) and child abuse (54.6 percent) were considered major type of human rights violations. Human rights commission is a major human rights protective mechanism according to 89.4 percent of the youth.

Human rights Awareness among Youth: Awareness of youth on values and principles, rights related to humanitarian concerns, democratic governance, rights of the marginalized and awareness on human rights protective mechanism have been analysed. Most of the youth considered dignity (86.5 percent), Mutual respect ( 98 percent), liberty (87.2 percent), and right to life (79.6 percent) were the most acceptable valuesand principle of human rights and the awareness level of these were very high. Rights related to the humanitarian concerns is economic, social and cultural rights of individual guaranteed by the law. The youths' level of awareness was relatively high on social security (82.1 percent), family rights (83 percent), right to health (83.7 percent) right to clean environment (72.2 percent) cultural rights (80.5percent) and right to education ( 81.8 percent). However, the youth were not much aware about the rights on economic efficiency ( 56 percent), religious diversity (6o.8 percent), right to work ( 55.7 percent) and right to property (61.2 percent). 
The study noticed that youth consciousness on civil and political rights is essential for better citizenship and democratic governance. It is essential that public participation (82.2 percent), freedom of speech and expression (81.5 percent), thought and belief (80.7 percent) and movement (79.9 percent) were reflected as major rights in this category. The right against cruel and unusual punishment, police torture, unlawful arrest and arbitrary detention are essential to liberate individuals from ungraceful and in humane acts of the authorities of the State. The youth believe that women should be protected from domestic violence. The youth awareness on girls' education (69.7 percent), rights of migrant workers (59.1 percent), prisoners' rights (75.1 percent), mainstreaming of marginalized (67.3 percent) and reservation for persons with disability (75.8 percent) were moderately high. With regard to corporal punishment, most of the youth (58.7 percent) were against corporal punishment on children. 72.8 percent of the youth were against female foeticide because they were aware of the child's right to survival and protection.

\begin{tabular}{|c|c|c|c|c|c|c|}
\hline \multicolumn{7}{|c|}{$\begin{array}{l}\text { Table } 2 \\
\text { Awareness among NSS Volunteers and NYK Club Members }\end{array}$} \\
\hline Dimension & Group & $\mathbf{N}$ & Mean & Std. Deviation & t-value & P-value \\
\hline \multirow{2}{*}{$\begin{array}{l}\text { Human rights Values } \\
\text { and Principles }\end{array}$} & NYK & 340 & 32.3 & 4.865 & \multirow[t]{2}{*}{$8.355^{* *}$} & \multirow[t]{2}{*}{$<0.001$} \\
\hline & NSS & 336 & $35 \cdot 44$ & 3.927 & & \\
\hline \multirow{2}{*}{$\begin{array}{l}\text { Humanitarian } \\
\text { Concern }\end{array}$} & NYK & 340 & 41.36 & 6.782 & \multirow[t]{2}{*}{$6.257^{* *}$} & \multirow[t]{2}{*}{$<0.001$} \\
\hline & NSS & 336 & 44.6 & $5 \cdot 305$ & & \\
\hline \multirow{2}{*}{$\begin{array}{l}\text { Democratic } \\
\text { Governance }\end{array}$} & NYK & 340 & 35.01 & 5.15 & \multirow[t]{2}{*}{$3.188^{* *}$} & \multirow[t]{2}{*}{$<0.001$} \\
\hline & NSS & 336 & 36.31 & 4.458 & & \\
\hline \multirow{2}{*}{$\begin{array}{c}\text { Rights of } \\
\text { Marginalized }\end{array}$} & NYK & 340 & 34.66 & $5 \cdot 51$ & \multirow[t]{2}{*}{$3.694^{* *}$} & \multirow[t]{2}{*}{$<0.001$} \\
\hline & NSS & 336 & 36.18 & 4.052 & & \\
\hline \multirow{2}{*}{$\begin{array}{c}\text { Human Rights } \\
\text { Protective } \\
\text { Mechanism }\end{array}$} & NYK & 340 & 29.94 & $4 \cdot 979$ & \multirow[t]{2}{*}{$1.728^{\mathrm{ns}}$} & \multirow[t]{2}{*}{0.085} \\
\hline & NSS & 336 & 30.6 & 3.861 & & \\
\hline \multirow[t]{2}{*}{ HR score } & NYK & 340 & 173.27 & 19.259 & \multirow[t]{2}{*}{$7.077^{* *}$} & \multirow[t]{2}{*}{$<0.001$} \\
\hline & NSS & 336 & 183.31 & 13.506 & & \\
\hline
\end{tabular}

Youth became aware of the mechanism for protecting human rights in society. The UDHR is the basis of human rights for 61.9 percent of young people, and is part of the State's foreign responsibility. Youth was informed, with respect to 80.8 per cent responses, of the definition of fundamental rights. Each individual has the right to defend violations of human rights, as proven by $79.4 \%$ of young people's positive responses. Most youth (72.6 percent) said a human rights 
commission could slow down violations of human rights in society. 78.36 percent acknowledged a prompt resolution of cases related to breach of human rights tribunal's successful involvement in the speedy trial. 82.3 per cent of young people have been aware of the fact that each person has the right to receive free legal aid and a fair trial in the free legal aid system. Human rights organisations ' role in protecting human rights also plays a positive role in preserving peace and justice in society. The Nazi volunteers are more aware of human rights than the members of the NYK club. The level of consciousness of NSS female volunteers is higher than female members of the NYK club, but male NYK members are highly sensitive than male NSS volunteers. NSS and NYKS were the youth welfare programmes with the agenda to internalize the youth with values of humanitarianism and democratic concerns.

The comparison of human rights awareness among NSS and NYK members was done by using independent $t$ test. The results given in table 2 shows the mean values being higher for NSS volunteers compared to NYK club members. It reveals that emphasis on human rights is significantly better for the volunteers of National Service Scheme. The study further reveals that all the t-values are significant at o.o1 level of significance except the awareness on human rights protective mechanisms and its shows that, there is no much significant difference between the awareness level of NSS volunteers and NYK club members on human rights protective mechanisms.

Advocacy role of Youth in Promoting Human Rights: Youth involvement in the protection and promotion of human rights has been studied through the prospect of counteroppression of violations of human rights, strengthening and restoring the perspectives of the systems of human rights and empowerment of the education system. The study observed that the youth effort through anti-oppressive practice on human rights violations were highly appreciable because they accepted their ability to take action in adverse situations such as child labour (83.3 percent), misuse of religion (71.3 percent), caste discrimination (85.2 percent), child abuse and beggary (87.2 percent) and violence against women. Most of the youth (74.5 percent) responded that the State cannot accuse an individual for raising voice against the ungraceful activities of the authorities. The youth responded against eviction of slum dwellers for constructing of road without any rehabilitation services (82.9 percent) and destruction through man- made disaster (62.9 percent). Further, 52.5 percent of the youth felt that, refugees were not considered as normal citizens of the country.

Strengthening and restoration of human rights mechanism and involvement of the youth were indicated in the study. It is noticeable that, 84.2 percent of the youth pointed that public participation in democratic society is mandatory for the process law making. According to the responses of 65.5 percent of the youth felt, educational and employment reservations are needed to maintain equality. Most of the youth (72.7 percent) advocated people- centered approach to prevent and redress human rights violations. The provision of prison rehabilitation services, human rights training programmes and the effective role of media can strengthen the human rights mechanisms. The study further ascertained that there is need for significant human rights educations for the empowerment of youth. Human rights education is a way to redress abuses and maintain peace in the society according to 78.3 percent of the respondent. It is a means to achieve social transformation and to imbibe social justice. As per findings 74 percent of the youth stated that, human rights education is a path finder to attain human rights culture and sustainable development. The study further noted that 59.3 percent of youth moderate and 28.6 percent were high in their effort for promoting human rights. The advocacy role of youth in activism was thus recognized by the intervention concentrating of the youth's ability to protect 
and promote individual human rights. The study showed more than NYK club members that NSS volunteers were a good shade of advocacy.

\section{Table 3}

\section{Advocacy level of NSS and NYK}

\begin{tabular}{|c|c|c|c|c|c|c|}
\hline Dimension & Group & $\mathbf{N}$ & Mean & Std. Deviation & t-value & P-value \\
\hline \multirow{2}{*}{$\begin{array}{c}\text { Anti-oppressive } \\
\text { practice }\end{array}$} & NYK & 340 & 41.13 & 6.94 & \multirow[t]{2}{*}{$7.693^{* *}$} & \multirow[t]{2}{*}{$<0.001$} \\
\hline & NSS & 336 & 45.40 & 6.10 & & \\
\hline \multirow{2}{*}{$\begin{array}{l}\text { Strengthening } \\
\text { and restoration }\end{array}$} & NYK & 340 & 41.39 & 5.33 & \multirow[t]{2}{*}{$1.256^{\mathrm{ns}}$} & \multirow[t]{2}{*}{0.210} \\
\hline & NSS & 336 & 40.88 & 4.15 & & \\
\hline \multirow{2}{*}{$\begin{array}{c}\text { HRE for } \\
\text { Empowerment }\end{array}$} & NYK & 340 & 41.63 & 5.82 & \multirow[t]{2}{*}{$0.98 \mathrm{o}^{\mathrm{ns}}$} & \multirow[t]{2}{*}{0.328} \\
\hline & NSS & 336 & 42.10 & 5.40 & & \\
\hline \multirow[t]{2}{*}{ Advocacy } & NYK & 340 & $124 \cdot 31$ & 14.07 & \multirow[t]{2}{*}{$3.676^{* *}$} & \multirow[t]{2}{*}{$<0.001$} \\
\hline & NSS & 336 & 128.38 & 11.80 & & \\
\hline
\end{tabular}

** significant at 0.01 level; ns non-significant at 0.05 level

The comparison of mean values in the table 3 reveals that mean score is higher for NSS volunteers. It shows that NSS volunteers take high level of advocacy effort when compared to NYK club members. It is due to the organized structure and social oriented activities of NSS programmes. The study further reveals that, the $t$-values of concept of strengthening and restoring perspective and empowerment through HRE perspectives were non-significant at 0.05 levels. It reveals that the advocacy effort on these concepts had no much significant difference between NSS volunteer and NYK club members.

\section{Implications and Policy Recommendations}

Human Rights Education (HRE) can act as a defence against violation. It can change attitudes and behaviours and aim to provide an understanding of issues, can equip people with the skills to articulate their rights, and can communicate this knowledge to others. Human rights should be school, college and university curriculum. Self Help Groups, Anganvadies, and youth clubs can be made channels to promote human rights education. The knowledge and skill on human rights can be imparted to its members and NGOs, Panchayath Raj Institutions (PRIs) and local bodies can also take steps to create awareness about human rights among the marginalized groups. Human rights education should be made compulsory for civil servants including police and other law enforcement personnel. Protection of Human Rights Acts 1993 has provision for human rights courts but the implementation of these courts is still on papers in Kerala. It helps to dispose the cases at the earliest and human rights violations can be reduced. Community based human rights protection forums should be organised at grass root level. This can be constituted at panchayath level with due representation of villages leaders, social workers, elected representatives as part of 
dispute resolution and grievance redressal mechanisms. The initiative of Voluntary organisations has to be enriched with the activities and networking to reach people of all walks of life. The campaign and networking need to be aimed at strengthening and reinforcing monitoring, interventions and rehabilitation.

The programmes of NSS with the content on human rights especially in regular as well as special camping activities. Special lecture session can be arranged on human rights during the camps for ensuring the relevance of human rights protection and also the cases of human rights violations can be identified. The sessions can be held on collective rights of peoples, gender justice, right to environment and health, consumer rights, social and economic rights and Motor vehicle Act etc. The NSS volunteers should take efforts for disseminating knowledge on human rights in the adopted Villages. Create human rights protection as motto of NSS and implement it into the action plan of the yearly programmes. Protection of human rights has to be added in the agenda of NYK. Human Rights training programmes is essential to NYK club members to enrich them with the knowledge and skills for handling human rights issues. Combined effort of NSS and NYK can create a violation free society. NSS volunteers have to take part in activities of NYK and vice versa. It leads to develop a socialized way to protect the rights of themselves and others

Media advocacy on human rights leads to spreading awareness among the community. Usage of community radio, TV and other audio-visual aid's can help to propagate knowledge on human rights. Litigation is a way to protect the rights of the people. Citizens have to reach out to the legislative process. Citizen friendly legal service has to develop. Speedy trial and resolution mechanism has to be adopted. Make people free from fear on law providing authority such as police and court.

\section{Conclusion}

The youth involvement in the process for protecting and promoting human rights has been highlighted in the study. Human rights-based approach is needed in the implementation of youth welfare policies and programmes because youth is considered agent for progressive social change. An advocacy model for youth has been evolved on the basis of the activities on youth welfare policies and programmes in India, especially the programmes because the activities of NSS and NYK is for the well-being of youth with their involvement in the process of community development. The effort of youth to uphold human rights has been compared to their level of awareness, and a low awareness has been found that the attempts made to protect human rights are not good enough. The action orientation for human rights among were inserted through the internalizing them with the human rights culture. The study also revealed that human rights awareness of youth and their effort to promote and protect human rights protection were interrelated to each other because awareness can influence their advocacy effort.

\section{References}

Allen, P. (2002). Youth and philanthropy: Legal issues, practical consequences. New Directions For Philanthropic Fundraising, 49-66

Ashifa. K.M.(2016). Human Rights Education in India: Perspective and Practices. International Journal of Applied Research and Social Science. 3(15). 
Ashifa,K.M. Influence of Social Networking among Adolescent Youth, International Journal of Innovative Technology and Exploring Engineering ,2019: 8 (12S): 614-616. Retrieved from https://www.ijitee.org/wp-content/uploads/papers/v8i12S/L115110812S19.pd)

Council of European Portal. (2017). Compass: Manual for Human Rights Education with Young People. Retrieved from Council of Europe Portal: https://www.coe. int/en/web/compass /introducing-human -rights-education

Flanagan, C. A., \& Christens, B. D. (2011). Youth Civic Development: Historical Context and Emerging Issues. New Directions for Child And Adolescent Development. 2011(134). Retreived from https://onlinelibrary.wiley.com/doi/abs/10.1002/cd.307

Human rights Watch. (2013).www.hrw.org. Retrieved from https://www.hrw.org/sites/default/files/reports/wr2o13

Kaur, N. (2009). An Evaluative Study of Human Rights Education in the Curriculum of School Education in Punjab. Unpublished Ph.D Thesis, Guru Nanak Dev University, Amrtisar.

Kenya. (2014). Education For All: the 2015 national review. Ministry of Education, Science and Technology.

Sarfaty, G. A. (2009). Why Culture Matters in International Istitutions : The marginality of Human Rights at the World Bank. The Americal Journal of International Law, 647-683.

Thakkar, K. (1997). Human Rights and the Law: National and Global Perspectives. Mumbai: Snow Whit ePublications.

Tolman, J. (2000). How? Building Blocks for Human Right Education. In N. Flowers, The Human Rights Education Hand Book. Minneapolis: Human Rights Resource Center, University of Minnesota.

United Nations. (2008). www.un.org. Retrieved from General Assembly Marks 6o Years of Universal Human Rights Declaration by Adopting Its Own, Pleading to Enhance Dialogue Among Peoples: https://www.un.org/press/en/2 0o8/ga10795 .doc.htm

United Nations. (2014). www.un.org. Retrieved from Human Rights: https://www.un.org/en/sections/issuesdepth/human-rights/ 